\title{
KONSEP VISUAL SISTEM SARANA ISYARAT PENUNJUK (SIGN SYSTEM) DI KAMPUS SYAHDAN BINUS UNIVERSITY
}

\author{
Rina Kartika \\ Jurusan Desain Komunikasi Visual, Fakultas Komunikasi dan Multimedia, \\ Bina Nusantara University, Jln. K.H. Syahdan No. 9, Palmerah, Jakarta Barat 11480 \\ rinakartika@binus.edu
}

\begin{abstract}
Limited signage facilities in Syahdan Campus of Binus University, has often been the cause of the disruption of the activities of the users who are unfamiliar with the room layout in the building. Where in this case teaching and learning activities are only one of the activities conducted there, and it has to be considered that users are not only from among the faculty and students only, as regular users, but also visitors and guests as incidental users. Common problems in finding rooms that they have to go to, is usually only solved by asking someone else. Design of an effective, communicative, applicative and integrated sign system, is considered to be a solution to this problem.
\end{abstract}

Keywords: visual design, sign system

\begin{abstract}
ABSTRAK
Minimnya sarana isyarat penunjuk (signage) di Kampus Syahdan, seringkali menjadi penyebab terganggunya aktivitas para pengguna yang tidak terbiasa dengan tata letak ruangan di gedung tersebut. Di mana dalam hal ini kegiatan belajar mengajar tentunya hanya merupakan salah satu aktivitas di sana dengan penggunanya pun yang tidak hanya dari kalangan dosen dan mahasiswa saja, sebagai pengguna reguler, tapi juga pengunjung maupun para tamu sebagai pengguna insidentil. Masalah umum dalam mencari ruangan yang mereka tuju, biasanya hanya dapat terpecahkan dengan bertanya kepada orang lain. Pengadaan sign system yang komunikatif, efektif, aplikatif dan terpadu dipandang merupakan alternatif solusi yang tepat bagi permasalahan tersebut.
\end{abstract}

Kata kunci: konsep visual, sistem sarana isyarat, signage, sign system, semiotik 


\section{PENDAHULUAN}

Kampus Syahdan bagi civitas akademika Universitas Bina Nusantara (BINUS University) merupakan kampus yang memiliki beberapa keistimewaan. Selain sebagai kampus (gedung) pertama yang memiliki nilai sejarah bagi seluruh komunitas BINUS Group, kampus ini juga sekaligus merupakan pusat operasional utama civitas BINUS University. Minimnya sarana isyarat penunjuk (signage) di gedung ini seringkali menjadi penyebab terganggunya aktivitas para pengguna yang tidak terbiasa dengan tata letak ruangan di gedung tersebut. Masalah umum dalam mencari ruangan yang mereka tuju, biasanya hanya terpecahkan dengan bertanya kepada orang lain. Pengadaan sign system yang komunikatif, efektif, apllikatif, dan terpadu dipandang merupakan solusi yang tepat untuk permasalahan ini.

Hal tersebut tentunya sangat berpengaruh terhadap aktivitas para pengguna gedung secara umum. Kegiatan belajar mengajar hanya merupakan salah satu aktivitas, sedangkan penggunanya pun tidak hanya kalangan dosen dan mahasiswa saja sebagai pengguna reguler, tapi juga pengunjung maupun tamu sebagai pengguna insidentil. Sebagai gedung pusat aktivitas utama BINUS University, hal ini tentunya akan menjadi kondisi yang kurang menguntungkan bagi para pengguna gedung umumnya, maupun pengunjung dan tamu khususnya, yang belum terbiasa dengan tata letak ruang gedung tersebut. Tidak tersedianya sarana penerima tamu (reception), juga turut memperburuk kondisi ini.

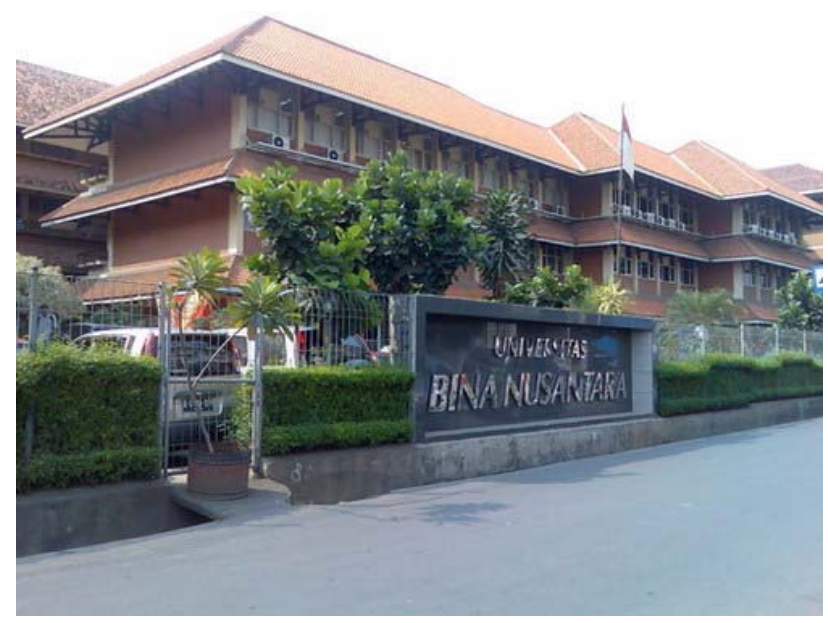

Gambar 1 Kampus Syahdan BINUS University

Berdasarkan permasalahan tersebut, maka solusi yang ditawarkan adalah melalui disiplin ilmu Desain Komunikasi Visual (DKV). Melalui Sistem Isyarat Penunjuk (Sign system) yang masih merupakan ruang lingkup disiplin ilmu ini, diharapkan diperoleh solusi yang komunikatif dan efektif. Pada tahap awal ini, ruang lingkup penelitian perancangan konsep visual sistim sarana isyarat ini adalah bagi Kampus Syahdan BINUS University. Hal ini diharapkan pada akhirnya dapat dikembangkan dan diaplikasikan ke gedung lain di lingkup BINUS University, maupun BINUS Group.

Tujuan penelitian ini adalah untuk merancang suatu konsep sistim sarana isyarat penunjuk bagi Kampus Syahdan BINUS University yang (1) Menjadi dasar bagi penelitian lanjutan untuk tahap perancangan, aplikasi, dan pengembangan; (2) Memudahkan aktivitas para pengguna gedung pada umumnya, maupun para pengunjung pada khususnya, dengan mengutamakan nilai-nilai komunikatif 
(mudah dimengerti), efektif (tepat guna), dan aplikatif (mudah diterapkan); (3) Merealisasikan kebijakan jurusan DKV Binus menuju BINUS 2020 melalui upaya penciptaan Lingkungan Kreatif serta Suasana Kuliah yang kondusif; (4) Memberikan nilai tambah estetika bangunan melalui elemen visual yang dapat mencerminkan 'Semangat Binusian'. Diharapkan sign system bermanfaat bagi seluruh pengguna gedung di lingkungan kampus Syahdan, yaitu mereka tidak kebingungan dalam mencari lokasi kelas atau unit kerja sehingga pekerjaan yang dilakukan efektif dan efisien.

\section{HASIL DAN PEMBAHASAN}

\section{Sign System}

Sign system adalah sebuah sistem penandaan yang sesuai dengan kebudayaan warga masyarakatnya, selain sebagai petunjuk, penamaan, penyampaian informasi singkat, dapat juga berupa aturan-aturan atau norma-norma yang dipakai dan diakui pada tempat tertentu dan dapat dimengerti oleh warga masyarakatnya.

Aplikasi dari sign system sendiri seringkali muncul dalam bentuk simbol-simbol yang mewakili suatu pesan atau makna tertentu yang telah 'disepakati' artinya oleh sekumpulan orang atau komunitas. Hal ini yang akhirnya membentuk kebudayaan manusia, sehingga manusia disebut sebagai 'mahluk budaya'. Kebudayaan sendiri adalah kesatuan dari gagasan-gagasan, simbol dan nilai yang mendasari hasil karya dan perilaku manusia, sehingga tidaklah berlebihan apabila dilanjutkan bahwa begitu eratnya kebudayaan dengan simbol yang diciptakan manusia sehingga manusia dapat disebut sebagai homo symbolicum. Kata symbol berasal dari kata Yunani, yaitu symbolos yang berarti tanda atau ciri yang memberitahukan sesuatu hal kepada seseorang. Menurut Charles S. Pierce (1839-1914), terdapat beberapa jenis tanda seperti indeks, ikon, symbol, yang merupakan patokan dasar ilmu semiotic / semiotika.

\section{Semiotik}

Menurut Kamus Besar Bahasa Indonesia, Semiotik adalah, "Segala sesuatu yang berhubungan dengan sistim tanda atau lambang dalam kehidupan manusia.” Sedangkan definisi Semiotic menurut Wikipedia Online Encyclopedia adalah:

Semiotics, or semiology, is the study of signs, both individually and grouped in sign systems. It includes the study of how meaning is made and understood. Semioticians also sometimes examine how organisms, no matter how big or small, make predictions about and adapt to their semiotic niche in the world). Semiotics theorises at a general level about signs, while the study of the communication of information in living organisms is covered in biosemiotics.

Ilmu ini disebut sebagai semiotic adalah semata-mata untuk menghormati John Locke (1632-1704) yang dalam bukunya yang berjudul An Essay Concerning Human Understanding (1690), yang pertama kali mencantumkan istilah "semeiotike" yang berasal dari kata Yunani "semiotikos" atau "semeion”, yang berarti "mark" atau "tanda".

Semiotic merupakan ilmu yang sangat bersifat fleksibel karena prosesnya tidak terjadi begitu saja, namun melalui proses yang sangat panjang dan bahkan terus berkembang hingga saat ini. Meski sudah menghasilkan sign system yang bersifat universal, namun terkadang semiotic harus mengalah kepada budaya. Setiap daerah di seluruh dunia memiliki kebudayaan asli yang masing-masing memiliki ciri khas tersendiri. Itu sebabnya terkadang ada beberapa sign system untuk sebuah objek yang sama, bisa berbeda antara daerah yang satu dengan daerah yang lain. 


\section{Kategori Sign System}

Menurut GSA (Graphic Sign Association) berdasarkan peletakan dan tingkat kekhususan informasi, sign system dapat dikategorikan menjadi (1) Temporary / Urgent Need Sign. Umumnya terletak pada sisi paling luar lingkungan penggunaannya. Fungsinya untuk mengatur sirkulasi pejalan kaki atau kendaraan (Welcome message, Security sign, dan lain-lain); (2) Exterior Approach Sign. Terletak pada sisi luar gedung dan berfungsi untuk mengidentifikasikan gedung yang bersangkutan (Building sign dan Entry sign); (3) Main Lobby. Berlokasi di lobby utama, tempat penghubung, maupun daerah percabangan yang menuju ke tempat lain (Directory, Branding, dan Lobby services); (4) Upper Floor Sign. Penunjuk menuju tempat yang lebih spesifik dalam lingkungan tersebut (Corridor, Identification dan lain-lain).

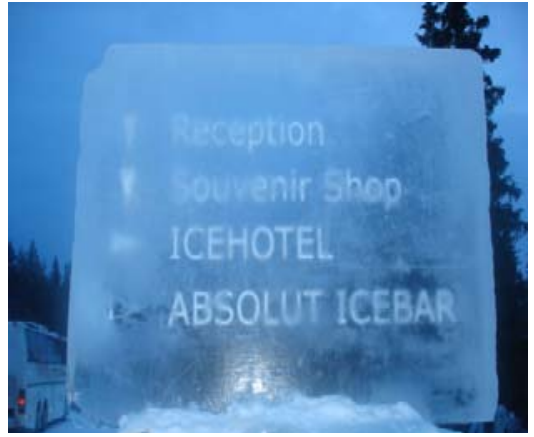

Gambar 2 Contoh Temporary/Urgent Need Sign

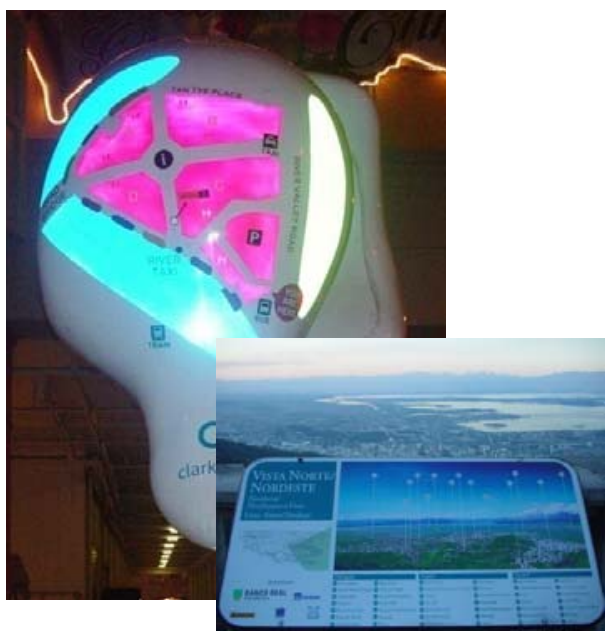

Gambar 4 Contoh Main Lobby

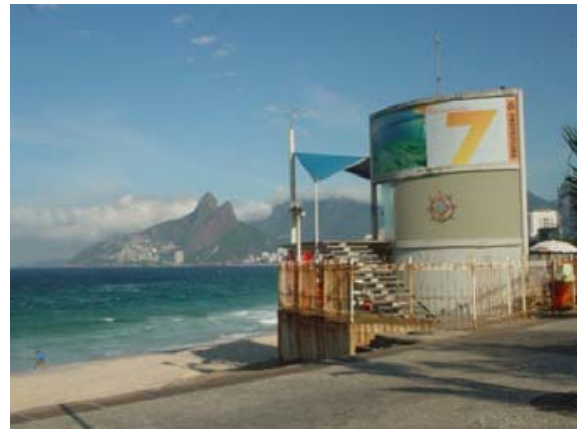

Gambar 3 Contoh Exterior Approach Sign

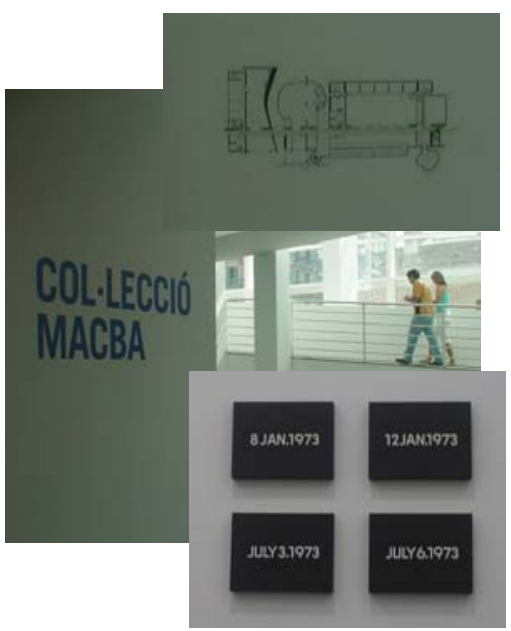

Gambar 5 Contoh Upper Floor Sign

\section{Material Dasar}

Sementara beberapa jenis material dasar yang umum digunakan dalam pembuatan sign system adalah (1) Kayu, dengan permukaan yang bertekstur dan ringan, tidak perlu teknologi tinggi dalam pengerjaannya. Kurang cocok untuk penggunaan outdoor karena lapuk; (2) Gelas biasa digunakan untuk penamaan gedung untuk outdoor karena sifatnya yang meneruskan cahaya dan memiliki permukaan yang bisa memantulkan; (3) Logam (alumunium dan besi). Alumunium mulai digunakan sebagai pengganti besi pada tahun 1950-an, karena ringan, kokoh, mudah dibuat, dan perawatan minim. Di sisi lain, besi umum digunakan sebagai bahan baku utama maupun struktur internal karena jauh lebih kuat; (4) Akrilik. Sering digunakan untuk outdoor karena tahan terhadap sinar UV. Tersedia 
dalam berbagai warna, mudah dalam pengerjaan serta relatif kuat; (5) Vinyl. Umumnya digunakan sebagai bahan cutting sticker. Material ini mudah dalam pengerjaannya, dan murah biayanya. Sering dikombinasikan dengan material lain pada penggunaannya; (6) Kain, biasanya digunakkan dalam bentuk banner yang memerlukan struktur tambahan sebagai penempatannya; (7) Digital Media, sangat tepat untuk sarana isyarat yang sifatnya non-permanen, karena mudah diganti bila diperlukan, dan dapat dicetak dengan menggunakan tinta anti UV untuk keperluan outdoor.

\section{BINUS University dan Kampus Syahdan}

BINUS University memiliki komitmen serta visi yang tinggi untuk menjadi pemimpin institusi pendidikan yang didasari oleh teknologi informasi, siap berkompetisi dan dapat menyesuaikan diri terhadap perubahan global. Misi BINUS University adalah (1) Untuk menerapkan program bidang pendidikan yang mendukung pengembangan dan aplikasi teknologi informasi, penguasaan dari bahasa asing, komunikasi, kepemimpinan, ketrampilan bisnis dan inovasi serta karakter yang baik; (2) Untuk menyediakan sebuah infrastruktur dan lingkungan yang memungkinkan untuk mengimplementasikan efektifitas dan efisiensi belajar dalam rangka menghasilkan lulusan yang trampil, kreatif dan inovatif; (3) Untuk memelihara keterkaitan dan hubungan antara aktivitas akademik dan permintaan socioeconomic global serta pengembangan industrial; (4) Untuk bekerja sama dengan institusi lain, dalam negeri maupun internasional, dalam rangka memastikan bahwa ketrampilan dan pengetahuan selalu diupdate sesuai dengan kebutuhan global; (5) Untuk menetapkan Binusian Community mempromosikan mutu, kebudayaan, nilai-nilai, dan susila pekerjaan di dalam organisasi.

Budaya mutu BINUS University adalah Trust in God, Continuous Improvement, Benchmarking,Sense of Closure, dan sense of belonging. Kampus Syahdan sendiri sebagai objek penelitian, menurut master plan, memiliki zoning (pembagian lokasi) sebagai berikut: (1) Entrance and Parking, yaitu loket parkir, Pos Sekuriti, dan lahan parkir; (2) Ruangan, yaitu ruang rektor, wakil rektor, akademis, fakultas, jurusan, kelas, lab/studio, AOC, SRSC, BAC, BEC, SAC, marketing, dan sekretariat UKM/ HMJ; (3) Facility, yaitu flamable and danger, emergency, toilet, building management, gudang, driver's room, klinik, ATM, hall, mushola, dan kantin.

\section{Brand Identity Manual BINUS University}

Brand Identity Manual adalah sarana petunjuk penerapan brand identity (lambang identitas) dari sebuah organisasi guna menjaga konsistensi komunikasi visual di berbagai materi aplikasinya. Umumnya sebuah Brand Identity Manual memuat peraturan penerapan sebuah brand identity seperti lambang organisasi (logo, logogram, logotype), jenis huruf, elemen grafis penunjang, dan aplikasi pada berbagai media. Ketentuan yang tercantum di dalam Brand Identity Manual umumnya bersifat baku dan sepatutnya ditaati dalam penerapannya agar terjaga konsistensi serta eksistensi komunikasi visual dari organisasi yang bersangkutan.

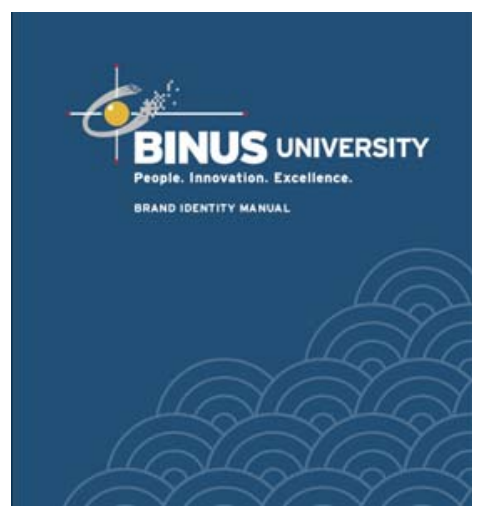

Gambar 6 Buku Brand Identity Manual BINUS University 


\section{METODE PENELITIAN}

Metode yang akan digunakan adalah sebagai berikut: (1) Metode riset, yaitu dialog dengan narasumber yang dirasa memiliki kompetensi di bidangnya; (2) Studi kepustakaan, yaitu riset pustaka pada perpustakaan fakultas seni, budaya, maupun teknis; (3) Metode observasi, yaitu berpartisipasi untuk melakukan pengamatan langsung atas sign system yang saat ini dipergunakan di Kampus Syahdan BINUS University. Pengamatan langsung dilakukan dengan melakukan simulasi untuk mencari ruangan tertentu tanpa ada bantuan informasi dari orang lain; (4) Analisis, yaitu menganalisis isi pesan (subjek) dengan karakteristik target audience dan kondisi penggunaan; (5) Sintesis, yaitu mencari solusi kreatif melalui disiplin ilmu desin komunikasi visual dengan konseptualisasi seperti ide / sketsa kreatif - berfikir lateral - mencari alternatif solusi dan pendekatan - penempatan tanda konsep desain - pemilihan material, visualisasi awal / sketsa, dengan menentukan eksekusi terbaik untuk dilanjutkan ke tahap ilustrasi komprehensif, dan argumentasi, dengan menyiapkan landasan argumentasi teori / konseptual atas solusi kreatif; (6) Verifikasi, yaitu uji kelayakan konsep desain dengan cara menguji persepsi target audience terhadap solusi kreatif yang ditawarkan; (7) Implementasi. Jika solusi dianggap tepat, maka rancangan sign system ini siap diapllikasikan dan penelitian siap dilanjutkan ke tahap berikut (gedung lain di BINUS University). Atau bahkan ke gedung lain di lingkup BINUS Group.

\section{HASIL DAN PEMBAHASAN}

Dimulai dengan tahap analisa, maka hasil penelitian Perancangan Konsep Visual Sistim Sarana Isyarat Penunjuk (Sign system) di Kampus Syahdan Binus University dapat dijabarkan sebagai berikut.

\section{Analisis SWOT}

Analisis SWOT dapat dijabarkan sebagai berikut. Pertama, Strength, yaitu (1) Fasilitas gedung Kampus Syahdan sudah cukup lengkap; (2) Sistem pendataan dan perawatan dari unit Building Management yang sudah cukup rapi; (3) Memiliki jurusan Desain Komunikasi Visual yang dapat bertindak sebagai konsultan sekaligus perancang bagi persiapan sign system; dan (4) Telah memiliki Brand Identity Manual sebagai sarana standarisasi aplikasi komunikasi visual lambang institusi. Kedua, Weakness, yaitu (1) Tata letak ruangan pada Kampus Syahdan yang mengakibatkan banyaknya sistim sirkulasi pengguna gedung yang tidak terpadu (ruangan yang menghadap ke sisi lain gedung dan tersembunyi dari sisi lain); (2) 'Comfort Zone' untuk merubah atau memperbaiki sesuatu yang sudah berjalan karena menganggap sign system yang sudah ada saat ini sudah berfungsi dengan cukup baik; dan (3) Kemungkinan perusakan (vandalisme) secara internal.

Ketiga, Opportunity, yaitu (1) Memberikan nilai tambah pada rancangan sign system dengan memasukkan unsur 'Semangat Binusian'; (2) Memberikan nilai tambah estetika bangunan melalui elemen visual pada rancangan sign system tersebut; dan (3) Dapat dikembangkan untuk gedung lain di lingkup BINUS Group. Keempat, Threat, yaitu (1) Budaya 'Malu bertanya sesat di jalan'; dan (2) Kemungkinan perusakan (vandalisme) terhadap secara eksternal.

\section{Konsep Desain: Pengaplikasian Brand Identity Manual}

Perancangan konsep desain dari Konsep Visual Sistim Sarana Isyarat Penunjuk ini tentunya tidak boleh bertentangan dan harus sejalan dengan ketentuan penerapan brand identity BINUS University yang terdapat pada Brand Identity Manual. 


\section{Jenis Huruf}

Jenis huruf yang dipergunakan disesuaikan dengan ketentuan yang terdapat pada Brand Identity Manual BINUS University, yaitu (1) Interstate, yang dipergunakan untuk informasi utama (Gambar 7); dan (2) ITC Garamond untuk untuk informasi tambahan (Gambar 8).

\author{
INTERSTATE LIGHT \\ ABCDEFGHIJKLMNOPQRSTUVWXYZ \\ abcdefghijkImnopqrstuvwxyz \\ INTERSTATE REGULAR \\ ABCDEFGHIJKLMNOPQRSTUVWXYZ \\ abcdefghijkImnopqrstuvwxyz \\ INTERSTATE BOLD \\ ABCDEFGHIJKLMNOPQRSTUVWXYZ \\ abcdefghijkImnopqrstuvwxyz \\ INTERSTATE BLACK \\ ABCDEFGHIJKLMNOPQRSTUVWXYZ \\ abcdefghijkImnopqrstuvwxyz
}

Gambar 7 Jenis huruf Interstate
ITC Garamond Book

ABCDEFGHIJKLMNOPQRSTUVWXYZ

abcdefghijklmnopqrstuvwxyz

ITC Garamond Book Italic

ABCDEFGHIJKLMNOPQRSTUVWXYZ

abcdefghijklmnopqrstuvwxyz

ITC Garamond Bold

ABCDEFGHIJKLMNOPQRSTUVWXYZ

abcdefghijklmnopqrstuvwxyz

ITC Garamond Bold Italic

ABCDEFGHIJKLMNOPQRSTUVWXYZ

abcdefghijklminopqrstuvwxyz

Gambar 8 Jenis huruf ITC Garamond

\section{Warna}

Penggunaan warna untuk sarana isyarat mengikuti spektrum warna resmi BINUS University yang telah ditetapkan dalam Brand Identity Manual (Gambar 9).

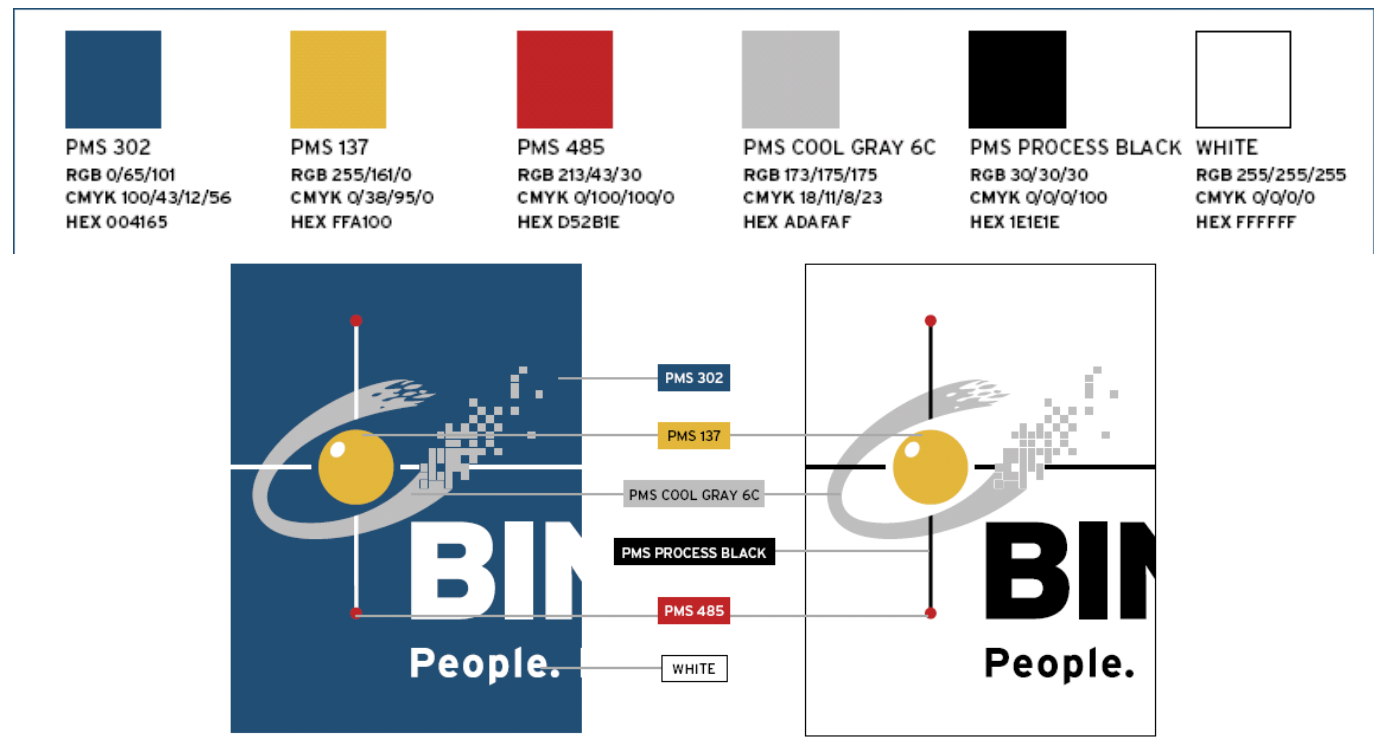

Gambar 9 Warna Standar BINUS University dan Aplikasinya

\section{Elemen Grafis}

Penggunaan elemen grafis (motif) untuk sarana isyarat mengikuti ketentuan yang telah ditetapkan dalam Brand Identity Manual BINUS University (Gambar 10). 


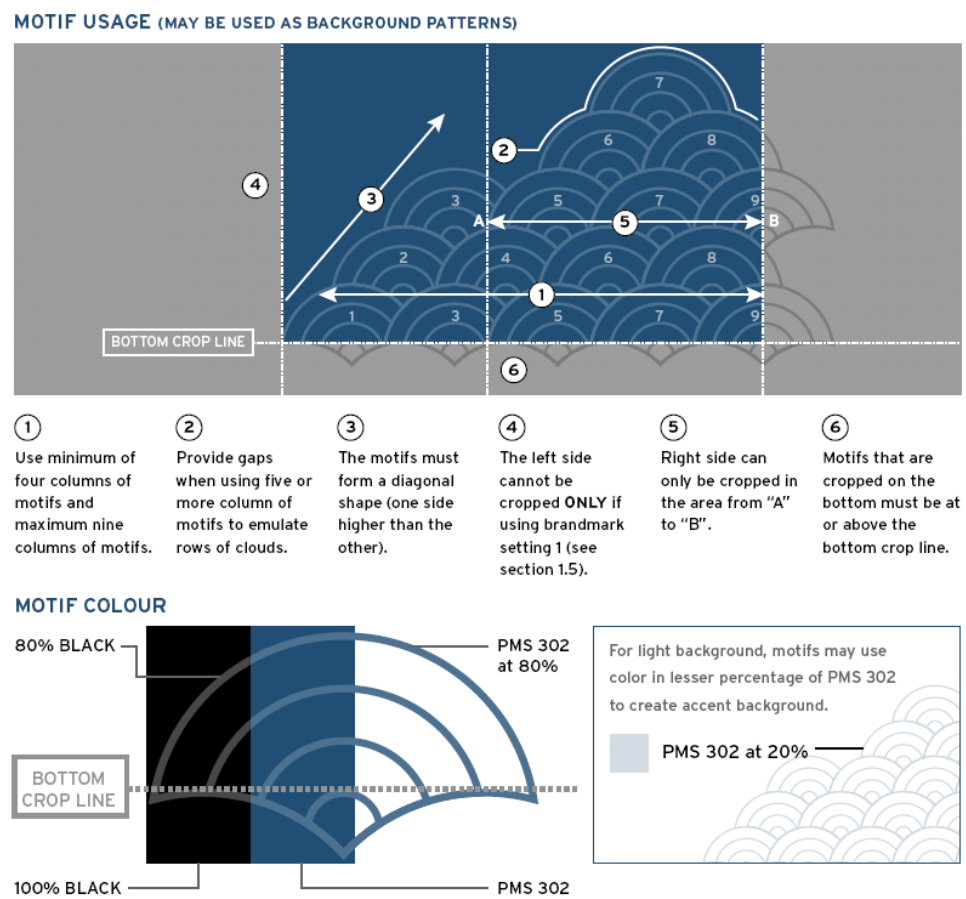

Gambar 10 Motif Standar BINUS University dan Penerapannya

\section{Lokasi Penempatan Sarana Isyarat Penunjuk}

Gedung Kampus BINUS Syahdan memiliki beberapa titik pusat keramaian khusus yang selalu menjadi jalur sirkulasi dari seluruh pengguna gedung ini untuk mengakses ruangan-ruangan di dalamnya. Pusat keramaian ini merupakan lokasi strategis bagi penempatan sarana isyarat penunjuk lokasi. Adapun titik-titik tersebut adalah sebagai berikut. Pertama, akses ke jalan Syahdan, terdapat 2 akses ke jalan Syahdan, di mana 1 akses digunakan sebagai pintu masuk kendaraaan serta pintu keluar untuk yang lainnya, sementara untuk arus keluar masuk manusia dapat menggunakan keduanya. Kedua, lokasi naik/turun penumpang kendaraan (drop zone), terdapat 4 drop zone, yakni 2 buah di bagian muka gedung dan 2 buah lainnya terletak di bagian belakang. Khusus drop zone di bagian muka berupa area terbuka (foyer) yang untuk kemudian mengarah ke bagian dalam sisi gedung bagian muka. Untuk drop zone di bagaian belakang, berupa lorong untuk menuju bagian dalam sisi gedung bagian belakang.

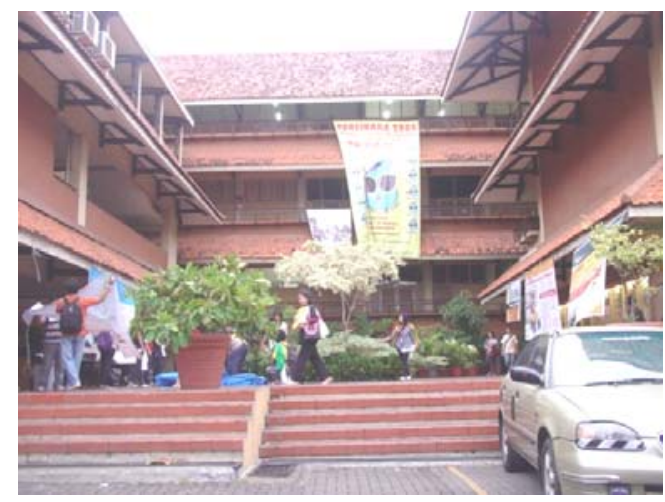

Gambar 11 Drop zone Pertama di Muka Gedung

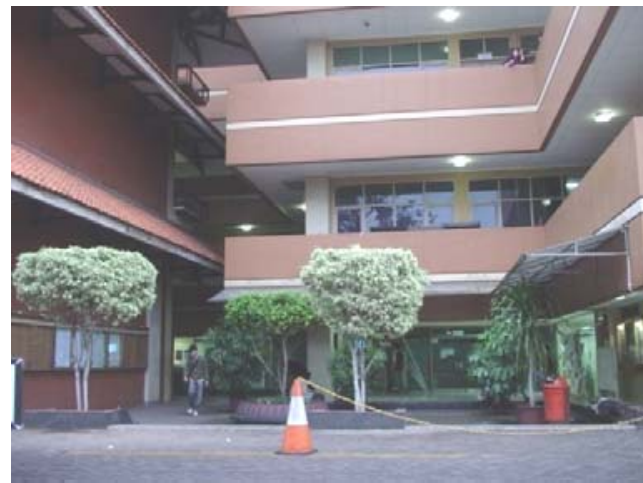

Gambar 12 Drop zone Kedua di Muka Gedung 


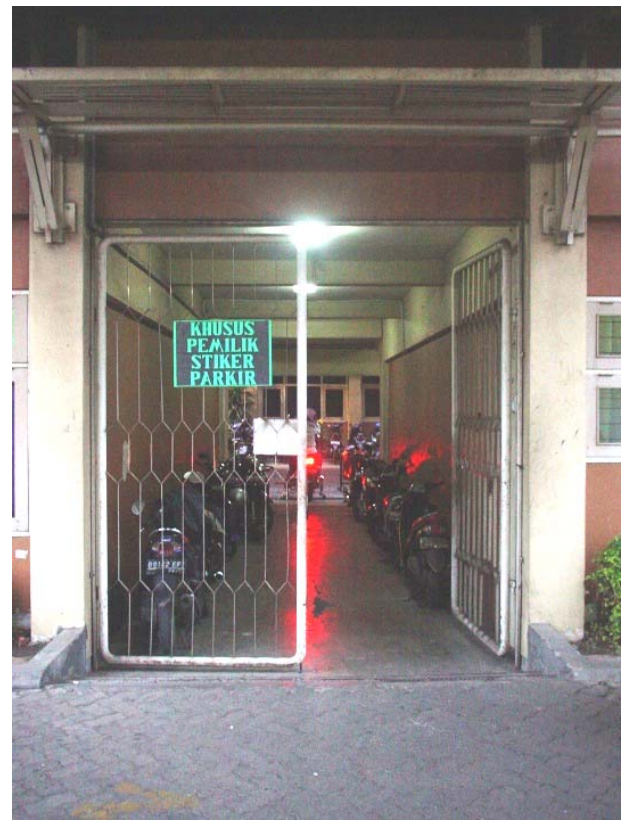

Gambar 13 Drop zone Pertama di Belakang Gedung

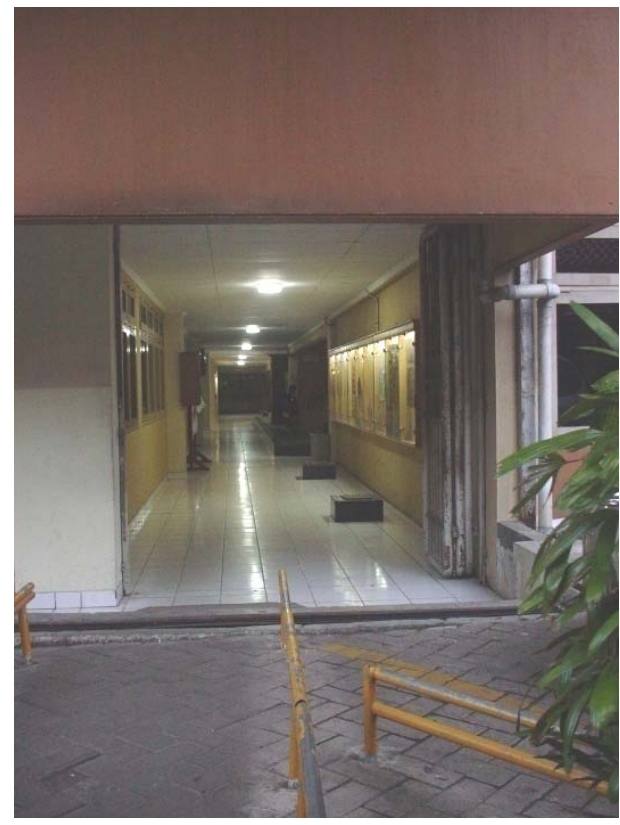

Gambar 14 Drop zone Kedua di Belakang Gedung

Ketiga, tangga utama, terdapat 4 tangga utama yang menghubungkan keempat lantai gedung kampus Syahdan. Dua buah terletak di sisi gedung bagian muka, dan 2 buah terletak di sisi gedung bagian belakang.

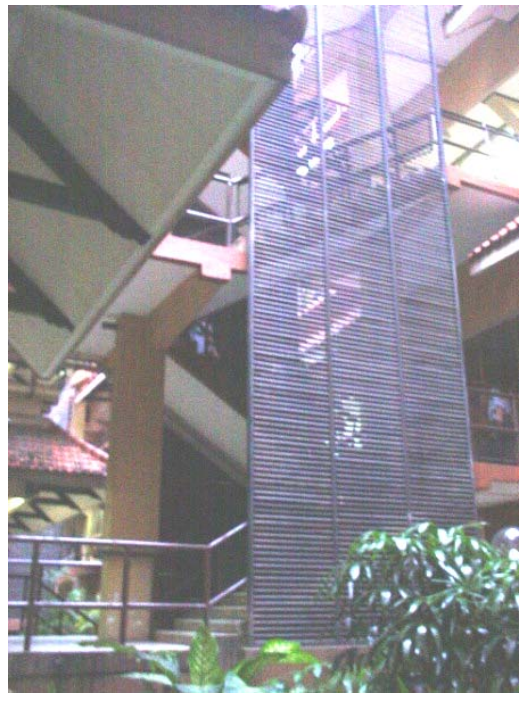

Gambar 15

Tangga Utama di Muka Gedung

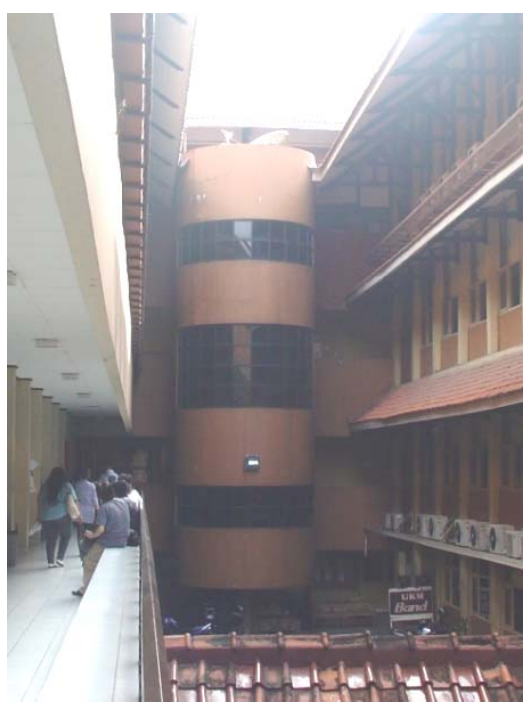

Gambar 16

Tangga Utama di Belakang Gedung

Keempat, ruangan, jenis ruangan dapat dibagai menjadi 2 jenis, yaitu ruang individu (satu pintu akses untuk satu ruangan, seperti ruang kelas, laboratorium, dan lain-lain) serta ruang kolektif (satu pintu akses menuju ruang-ruang lain di dalamnya seperti ruang akademis). 


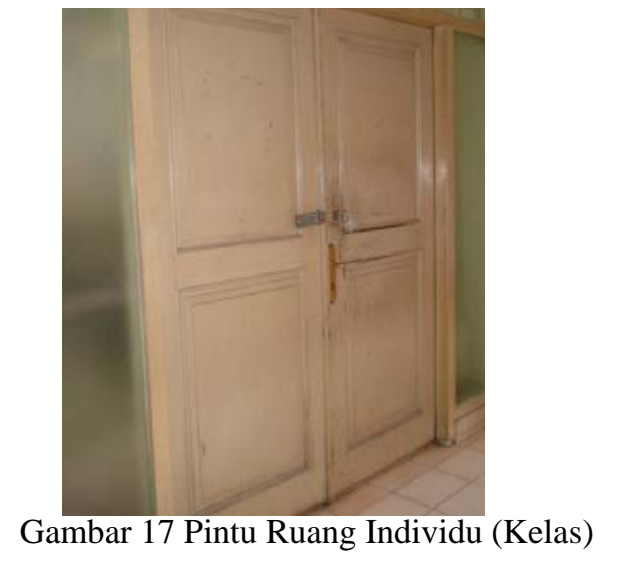

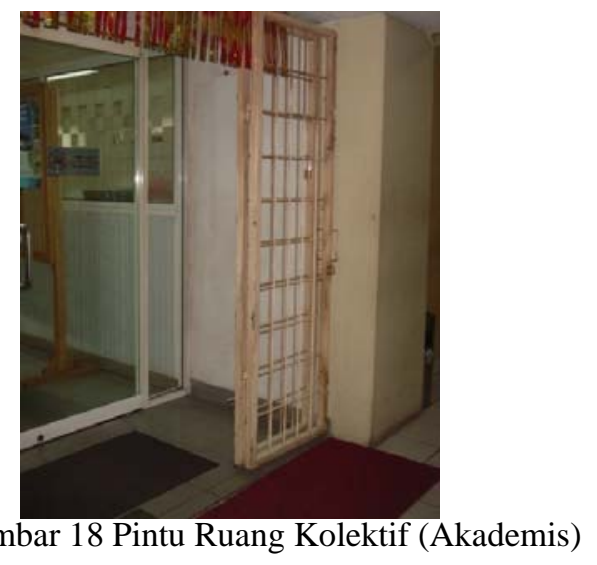

Lokasi penempatan sarana isyarat dan lingkungan sekitarnya akan sangat berpengaruh pada ukuran sarana isyarat tersebut, baik dimensi fisik sarana tersebut, maupun ukuran huruf yang dipergunakan. Sebuah studi menunjukkan bahwa tinggi huruf $10 \mathrm{~cm}$ akan cukup efektif terbaca oleh mata normal dari jarak 5 meter pada siang hari.

\section{Jenis Tanda Isyarat yang akan Digunakan}

Berdasarkan lokasi penempatannya, maka jenis tanda isyarat yang akan digunakan adalah sebagai berikut (1) Main Lobby: berbentuk Directory dengan standee yang ditempatkan pada kedua area drop zone bagian muka dengan gedung. Sedangkan untuk drop zone bagian belakang akan ditempatkan pada dinding gedung. Informasi yang ditampilkan dalam bentuk denah gedung; (2) Upper Floor Sign: digunakan pada tangga utama dan nama ruangan dengan ketinggian penempatan eye level. Khusus untuk ruang kolektif dapat ditambahkan denah pembagian ruangan di dalamnya; dan (3) Temporary / Urgent Need Sign: digunakan sebagai sarana petunjuk tambahan untuk lokasi yang tidak terlihat dari satu sisi lainnya dan ditempatkan dengan pada dinding gedung dengan ketinggian eye level. Dapat juga digunakan sebagai informasi arus kendaraan dan petunjuk pembagian lokasi parkir.

Material yang akan digunakan. Aspek pemilihan material erat kaitannya dengan teknik pengerjaan, di mana hal ini tentu pada akhirnya akan berpengaruh pada perawatan dan pembiayaan. Pemilihan material tergantung lokasi, jenis, karakter serta anggaran dana yang tersedia. Adapun material yang akan digunakan adalah kombinasi alumunium (sebagai material informasi utama) dengan Vinyl (sebagai material informasi tambahan). Khusus untuk Directory akan membutuhkan struktur dengan material dasar logam.

\section{Sketsa Rancangan}

Main Lobby

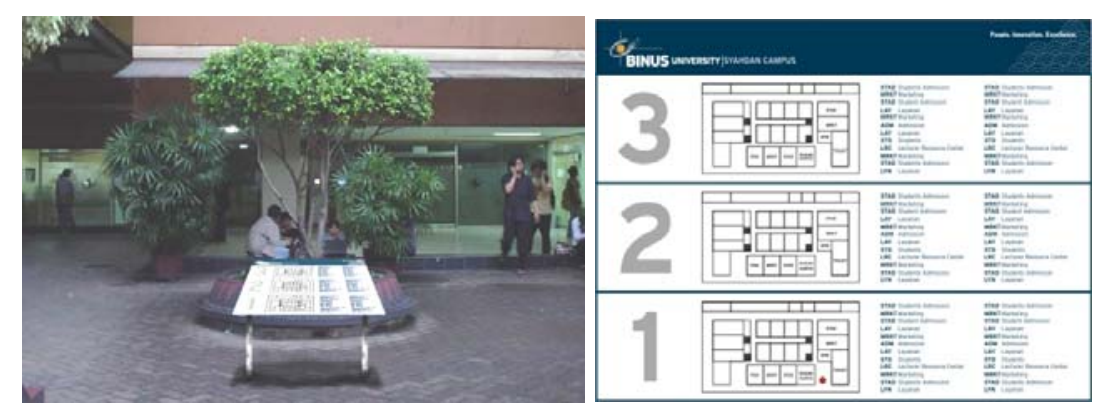

Gambar 19 Sketsa Directory Board pada Drop zone Kedua di Sisi Muka Gedung 
Upper Floor Sign
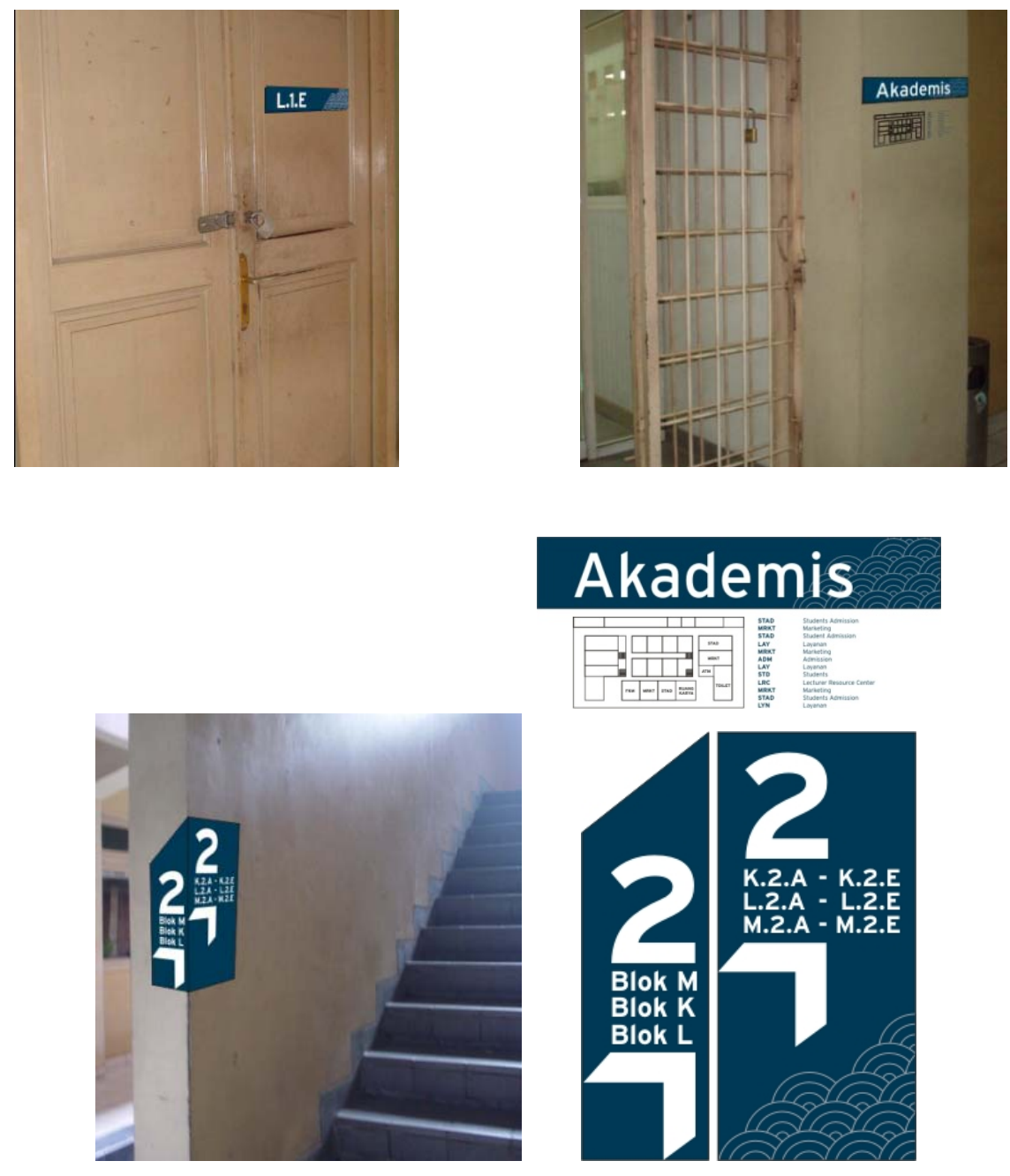

Gambar 20 Sketsa Sign System pada Ruang Individu, Ruang Kolektif, dan Tangga Utama

Temporary / Urgent Need Sign
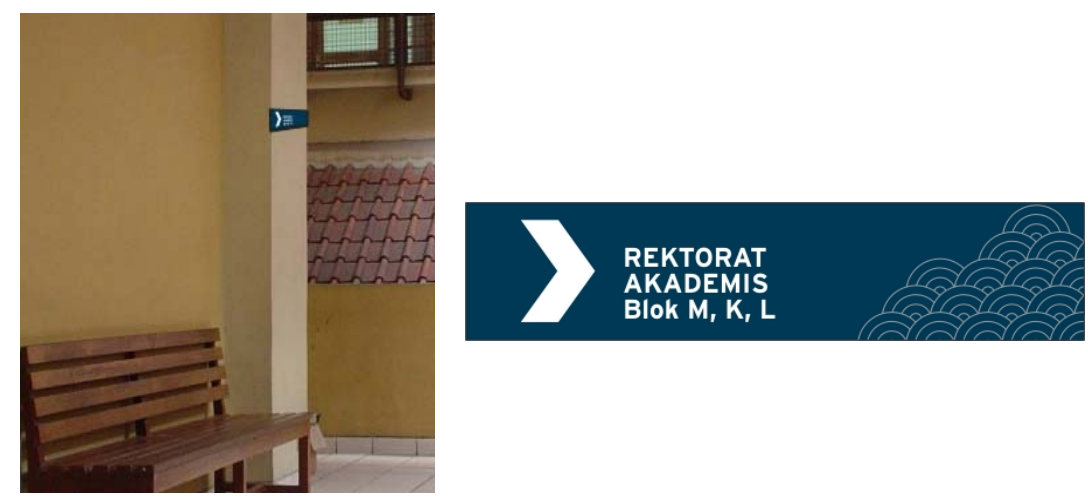

Gambar 21 Sketsa Sign System sebagai Penunjuk Ruangan yang Terletak pada Sisi yang Tak Terlihat dari Sisi Lainnya 


\section{SIMPULAN}

Padatnya aktivitas di gedung kampus Syahdan BINUS University menyebabkan perlunya sarana isyarat penunjuk yang komunikatif dan komprehensif. Tetapi hal ini tentunya tidak dapat melupakan unsur efektivitas serta efisiensi dalam segi biaya, mulai dari tahap perencanaan, hingga pelaksanaan, dan perawatan. Dengan memaksimalkan pemanfaatan seluruh potensi terkait yang telah dimiliki BINUS University, baik sumber daya manusia (seperti jurusan Desain Komunikasi Visual/ DKV, Building Management / BM, maupun bagian lain yang terkait) serta sarana yang dimiliki (Site plan, Brand Identity Manual serta dokumen penunjang lainnya), maka peluang untuk terciptanya sarana isyarat penunjuk yang komunikatif (mudah dimengerti), efektif (tepat guna), aplikatif (mudah diterapkan) serta efisien dari sisi biaya akan amat sangat dimungkinkan.

\section{DAFTAR PUSTAKA}

Anonim. (1994). Signing: Graphic standard manual PT Asuransi Tugu Mandiri, Jakarta.

Anonim. (2007). Brand identity manual, Jakarta: BINUS University.

Ardya W., O.. (2008). Environmental graphic design. Majalah Concept, vol. 4, edisi 23, Jakarta.

Frutiger, A. (1998). Sign and symbols: Their design and meaning, New York: Watson-Guptill Publications.

Ipsen, G. (2006). From environment to culture: Aspects of continuity. Sign systems studies journal, vol.34(1), London: Tartu Univerisity Press.

Nöth, W. (2003). Semiotic foundations of the study of pictures, Sign systems studies journal, vol.31(2), London: Tartu Univerisity Press.

Panero, J., and Zelnik, M. (1980). Human dimension and interior space, London: Whitney Library.

Woodson, W.E. (1993). Human factor design book, New York: McGraw-Hill. 